\title{
THE ENDOCANNABINOID SYSTEM: CRITICAL FOR THE NEUROTROPHIC ACTION OF PSYCHOTROPIC DRUGS
}

\author{
Parichehr Hassanzadeh \\ Research Center for Gastroenterology and Liver Diseases, Shahid Beheshti University of Medical \\ Sciences, Tehran, Iran
}

There is growing evidence that neurotrophins besides their well-established actions in regulating the survival, differentiation, and maintenance of the functions of specific populations of neurons, act as the potential mediators of antidepressant responses. Previous studies on the regulation of nerve growth factor (NGF) levels by psychotropic medications are limited in scope and the underlying mechanism(s) remain elusive. In this review, the latest findings on the effects of pharmacologically heterogeneous groups of psychotropic drugs on NGF contents in the brain regions involved in the modulation of emotions are summarized. Moreover, the therapeutic potentials of the endocannabinoid system which is linked to depression and/or antidepressant effects and appears to interact with neurotrophin signalling, are reviewed. New findings demonstrate that endocannabinoid system is involved in the mechanisms of action of certain psychotropic medications including neurokinin receptor antagonists and that these are mediated via the upregulation of brain regional levels of NGF. This provides a better understanding of the pathophysiological mechanisms underlying neuropsychiatric disorders, leading to novel drug designs. Biomed Rev 2010; 21: 31-46.

Key words: endocannabinoids, NGF, psychotropics, brain

\section{INTRODUCTION}

Depression is a serious and widespread mental disorder with high relapse rate which is characterized by an array of disturbances in emotional behavior, memory, neurovegetative functions and hedonic processing (1). The neurobiological mechanisms subserving the development, manifestation, and treatment of depression are complex. There is ample evidence that disturbances in monoaminergic signalling and glucocorticoid activity are involved in the pathophysiology of depression (2-4). However, the monoamine-based antidepressants do not fulfil the expectations in terms of onset of action, efficacy, and tolerability. This urges the need for the development of new antidepressants with novel mechanisms of action. Recent studies suggest a novel - neuroprotective - role for the adipose-derived hormone (adipokine) leptin, which was originally discovered to control energy

Received 19 December 2010, accepted 28 December 2010

Correspondence: Dr Parichehr Hassanzadeh, P.O. Box 19835-187, Tehran, Iran. Tel.: +98 212243 2515,

Fax:+98 212243 2517, E-mail: Pari_has@yahoo.com 
homeostasis and body weight. Indeed, the localization of leptin receptor in limbic structures prompted the researchers to investigate the therapeutic potential of leptin in animal models of depression $(5,6)$. In parallel, there has been growing interest in the assessment of the effects of psychotropic drugs on intraneuronal signal transduction and neurotrophins $(7,8)$. Neurotrophins are family of proteins consisting of nerve growth factor (NGF), brain-derived neurotrophic factor (BDNF), neurotrophin 3 (NT-3), NT-4/5, and NT-6 which regulate the survival, development, and function of neurons $(9,10)$; both pro-NGF and pro-BDNF should also be appreciated. The cellular actions of neurotrophins are mediated by two types of receptors; a high affinity tyrosine kinase (Trk) receptor, and a low affinity pan-neurotrophin receptor $\left(\mathrm{p} 75^{\mathrm{N}-}\right.$ ${ }^{\mathrm{TR}}$ ). Each Trk receptor is preferentially activated by one or more neurotrophin; TrkA by NGF, TrkB by BDNF and NT4/5, and TrkC by NT-3 (Fig. 1), leading to a number of cellular responses (11). Although the long-term trophic effects of neurotrophins depend on gene regulation, the cytoplasmic effectors activated by neurotrophins exert a wide range of more rapid actions including morphogenetic and chemotropic effects on developing neurons (12-14), modulation of neuronal excitability (15), and synaptic transmission $(16,17)$. Neurotrophins are also involved in the specific aspects of neuronal plasticity $(18,19)$, a term used to describe a great variety of changes in neuronal structure and function. Neu- rotrophins exert neuroprotective effects under pathological conditions which might be important for neurodegenerative and psychiatric diseases (20). Dysfunction in neurotrophinmediated signalling mechanisms appears to be implicated in the pathogenesis of a number of psychiatric disorders such as psychosis, depression, mania, and obsessive compulsive disorders $(21,22)$. It is worth mentioning that acute or chronic stress decrease cell proliferation and neurogenesis, an effect reversed by antidepressants $(23,24)$. In regards to the mechanism(s) through which antidepressants stimulate neurogenesis, the most convincing hypothesis suggests that antidepressants elicit such an effect by increasing the levels of neurotrophic factors such as BDNF (25). Long-term antidepressant treatment elevates both BDNF protein and $\mathrm{mRN}$ $\mathrm{A}^{\mathrm{BDNF}}$ levels and reverses stress-induced decrease in BDNF (26). Moreover, exogenous administration of BDNF displays antidepressant-like effects in animal models of depression (27). There are further reports suggesting the implication of BDNF in antidepressant action (28-34), however, few studies have measured NGF contents in multiple brain regions following the administration of psychotropic drugs and most of them have been limited in scope, examining a single drug class or brain region (35-37). In addition, the mechanism(s) by which psychotropic medications regulate NGF levels remained elusive. This, has been recently studied in our laboratory which will be discussed in a later part of this paper.

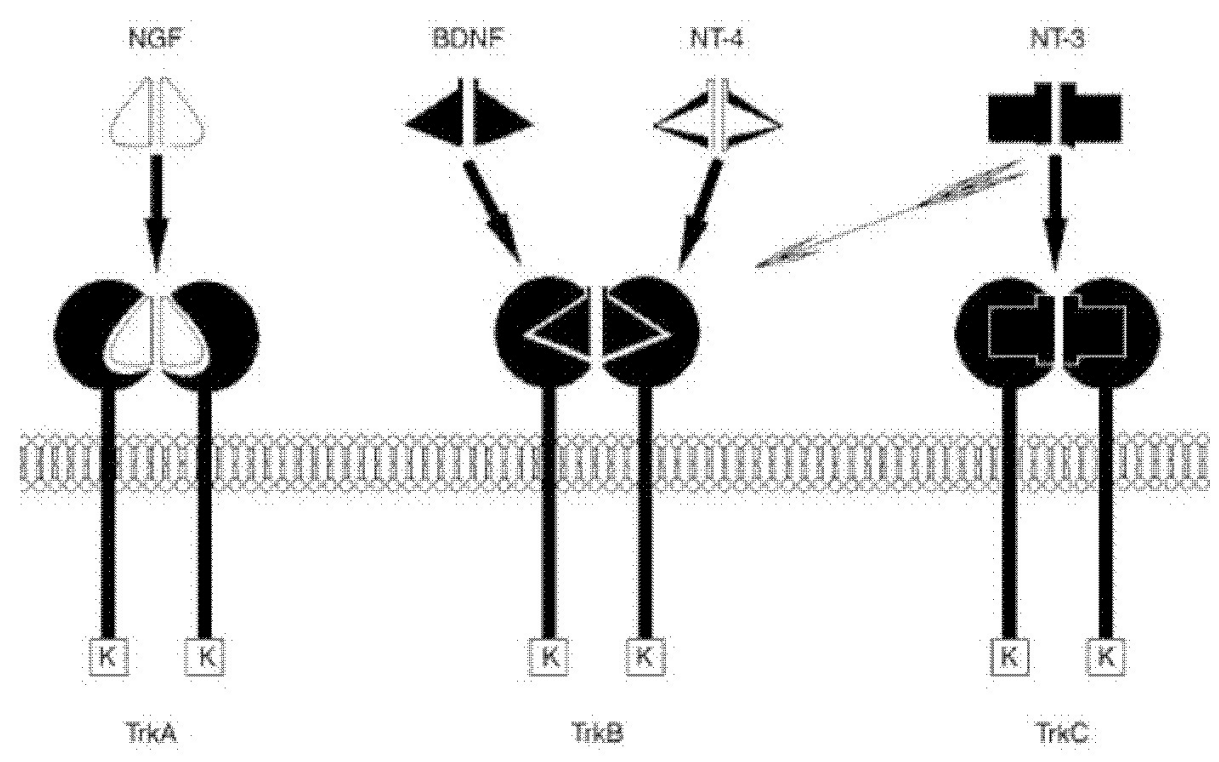

Figure 1. Neurotrophic tysosine kinase receptors. As shown, tyrosine kinase receptors are a family of receptors with a similar structure. (Adapted from Nat Rev Mol Cell Bio 2003; 4: 46-55). 


\section{FUNCTIONS AND THERAPEUTIC POTENTIALS OF NGF}

The search for target-derived factors that support the survival and growth of motor and sensory neurons led Rita LeviMontalcini to the discovery of the first neurotrophin, NGF (reviewed in 38-40). Subsequent studies (41-47) showed that NGF $(i)$ is synthesized and released by the target tissue of NGF-dependent axons and after binding to its receptors on axon terminals, is internalized and transported in a retrograde manner to the cell body, where it affects neuronal survival and differentiation, (ii) circulates throughout the body and is important for maintaining homeostasis, (iii) is critical for the memory and attention tasks that rely on the cholinergic septohippocampal pathway, (iv) exerts a modulatory role in the neuroendocrine-immune function, as well as inflammatory and neurological disorders, and $(v)$ promotes peripheral nerve regeneration in an animal model of sciatic nerve injury. Because of its antioxidant, angiogenic, and insulinotropic properties, NGF may be implicated in the molecular mechanisms of cardiometabolic diseases including coronary atherosclerosis, obesity, type 2 diabetes, and metabolic syndrome $(48,49)$. Moreover, NGF is involved in the suppression of food intake (50), and accelerating wound healing in skin and cornea ulcers (51-53). NGF produced and released by adipocytes and/ or mast cells may regulate the sympathetic innervation of adipose tissue. These may link adipose-derived NGF to the pathophysiology of both cardiometabolic and neuropsychiatric diseases $(54,55)$. Interestingly, treatment with nicergoline, an ergot alkaloid derivative with $\alpha_{1}$-adrenoreceptor-blocking and calcium antagonistic properties (56), has been shown to elevate the cerebral blood flow and improve the hemodynamics in aged rats with cerebral ischemia (57). These effects appear to be linked to the nicergoline-induced NGF enhancement in the aged rat brain (58). Therefore, the therapeutic potential of NGF in elderly individuals whose brain neurons are progressively dying with aging, merits further investigation. In recent years, NGF antagonism has been expected to be a highly effective therapeutic approach in acute or chronic pain states, and to be free of the adverse effects of traditional analgesic drugs (59).

\section{NGF AND NEUROPSYCHAITRIC DISEASES}

Experimental evidence suggests that antidepressant drugs and electroconvulsive treatment may act by enhancing central nervous system (CNS) levels of neurotrophins. According to in vivo experiments, NGF has the capacity to increase circulating concentrations of adrenocorticotropin and cor- ticosterone $(60,61)$. In addition, in vitro experiments have shown that NGF is able to induce the release of hypothalamic vasopressin, a neuropeptide which plays a pivotal role in the formation of social bonding $(62,63)$. Given these considerations, it would be tempting to speculate that NGF is involved in the molecular mechanisms of emotions by acting as a fine modulator of distinct neuroendocrine functions. In this context, the involvement of NGF in neuropsychiatric disorders such as dementia, depression, and schizophrenia has been reported (64-67).

We have recently shown that a wide range of psychotropic drugs including nortriptyline, isocarboxazid, citalopram, risperidone and fluphenazine elevate NGF levels in dose-dependent and brain-region specific fashion $(68,69)$. It is suggested that enhancement of NGF production may be specifically involved in the mechanisms of action of the antibipolar drugs such as lithium (70). However, lack of effects of antipsychotics including haloperidol, clozapine or olanzapine on BDNF or NGF levels in rat hippocampus has also been reported (71). It appears that differences in the experimental protocols, drug type, or dosing regimens might affect the study findings. Second-generation antipsychotics differ significantly with the first-generation antipsychotics in the regulation of brain NGF or BDNF levels, justifying the neurotrophin-mediated neuroprotection induced by the second-generation antipsychotics. Meanwhile, more extended treatments with atypical antipsychotics may be associated with the reduction of neurotrophins (72). These findings may have important clinical implications for the optimal therapeutic management of neuropsychiatric disorders.

\section{Antidepressants, NGF and neurokinin receptors}

In recent years, the potential anxiolytic- and antidepressant-like effects of compounds that target the neurokinin (NK) receptors, a class of $\mathrm{G}$ protein-coupled receptors which are found in the CNS and peripheral tissues, have attracted a growing interest. In this context, several selective and CNS-penetrating NK receptor antagonists which demonstrate efficacy in the treatment of emesis, anxiety, and depression have been synthesized (73-78). $\mathrm{NK}_{1}, \mathrm{NK}_{2}$, and $\mathrm{NK}_{3}$ receptors have been identified in both rodents and humans $(79,80)$. The localization of NK receptors in the cortex, hippocampus, amygdala, and septum may be consistent with the anxiolytic- and antidepressant-like effects of NK antagonists. As compared to the commonly used psychotropic medications, the effects of NK antagonists on neurotrophic factors are poorly characterized. There are a 
few studies indicating the differential regulation of the $\mathrm{NK}_{1}$ receptors and BDNF gene expression during inflammatory pain (81) or the increased levels of BDNF in $\mathrm{NK}_{1}$ receptor gene knockout mice (82). However, there is no previous report linking the NK antagonists to NGF. We have recently investigated the potential involvement of NGF in the mechanisms of action of NK receptor antagonists. According to our findings, the selective NK receptor antagonists dose-dependently elevate NGF levels in distinct brain regions relevant to the regulation of mood including the frontal cortex (83). As previously reported, the frontal cortex is likely to be involved in depression and antidepressant medications block or reverse stress-induced pathogenic deficits in this brain area $(84,85)$. The NK receptor antagonists can also elevate NGF concentration in the hippocampus which is supposed to be indicative of their neuroprotective effects (83). NGF plays a critical role in the hippocampal plasticity and learning and regulates hippocampal neurogenesis, a process that is mediated by the antidepressant treatment (86). Furthermore, NGF is involved in the cognitive function via the induction of acetylcholine release in the hippocampus (87). It is therefore reasonable to speculate that NK antagonists via enhancement of the hippocampal NGF improve psychopathology and particularly cognitive performance. In a recently conducted study, the $\mathrm{NK}_{1}$ antagonist, $\mathrm{N}$-acetylL-tryptophan, improved the cognitive neurologic outcomes after traumatic brain injury (88). The potential mechanisms through which the NK antagonists exert neuroprotective effects are discussed (89).

We have also shown the differential regulation of NGF levels by NK antagonists in the olfactory bulb and amygdala (83). NGF plays an essential role in the regeneration, maintenance, and development of the olfactory system of mammals (90). In addition, NGF facilitates cholinergic neurotransmission between the nucleus basalis and amygdala which play an important role in the cognitive functions (91). As a whole, it appears that enhancement of the brain regional levelsof NGF constitutes an essential part of the biochemical alterations induced by certain psychotropic medications including the NK receptor antagonists.

To gain a mechanistic insight into the process by which psychotropic drugs regulate brain NGF levels, we have investigated the potential involvement of the endocannabonid system which is linked to depression and/or antidepressant effects (92), and appears to interact with neurotrophin signalling (93-95). This, as well as other therapeutic potentials of the endocannabinoid system will be discussed herein.

\section{THE ENDOCANNABINOID SYSTEM}

The endocannabonid system refers to a group of neuromodulatory lipids and their receptors which are involved in a variety of physiological processes including the regulation of motor activity, nociception, memory, appetite, temperature, brain development, and brain reward processes (96-99). The existence of an endogenous cannabinoid system was demonstrated with the discovery of endogenous brain constituents, anandamide ( $\mathrm{N}$-arachidonoylethanolamine, AEA) and 2-arachidonoylglycerol (2-AG), collectively termed the endocannabinoids, which are synthesized on demand by neuronal cells. Endocannabinoids are not stored in the vesicles like other mediators and are inactivated through re-uptake and enzymatic hydrolysis in both neurons and astrocytes (Fig. 2) (100). They act as retrograde synaptic messengers (Fig. 3) and inhibit the release of different neurotransmitters in the hippocampus, cortex and striatum $(101,102)$. Endocannabinoids are ligands for the cannabinoid receptors including the

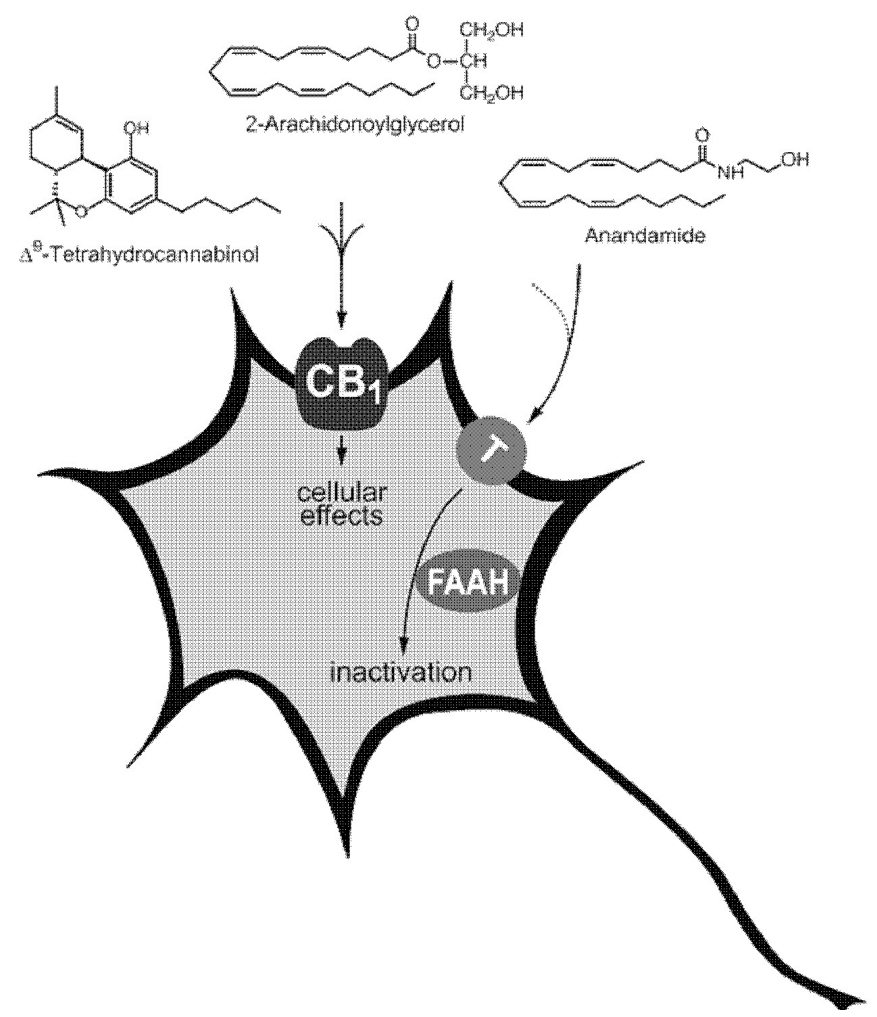

Figure 2. Inactivation of the endocannabinoids. Anandamide and 2-Arachidonoylglycerol are internalized by neurons through a high-affinity transport (T) mechanism. Once inside cells, endocannabinoids are hydrolyzed by fatty acid amide hydrolase (FAAH). (Adapted from Curr Med Chem 2002; 9: 663-676). 


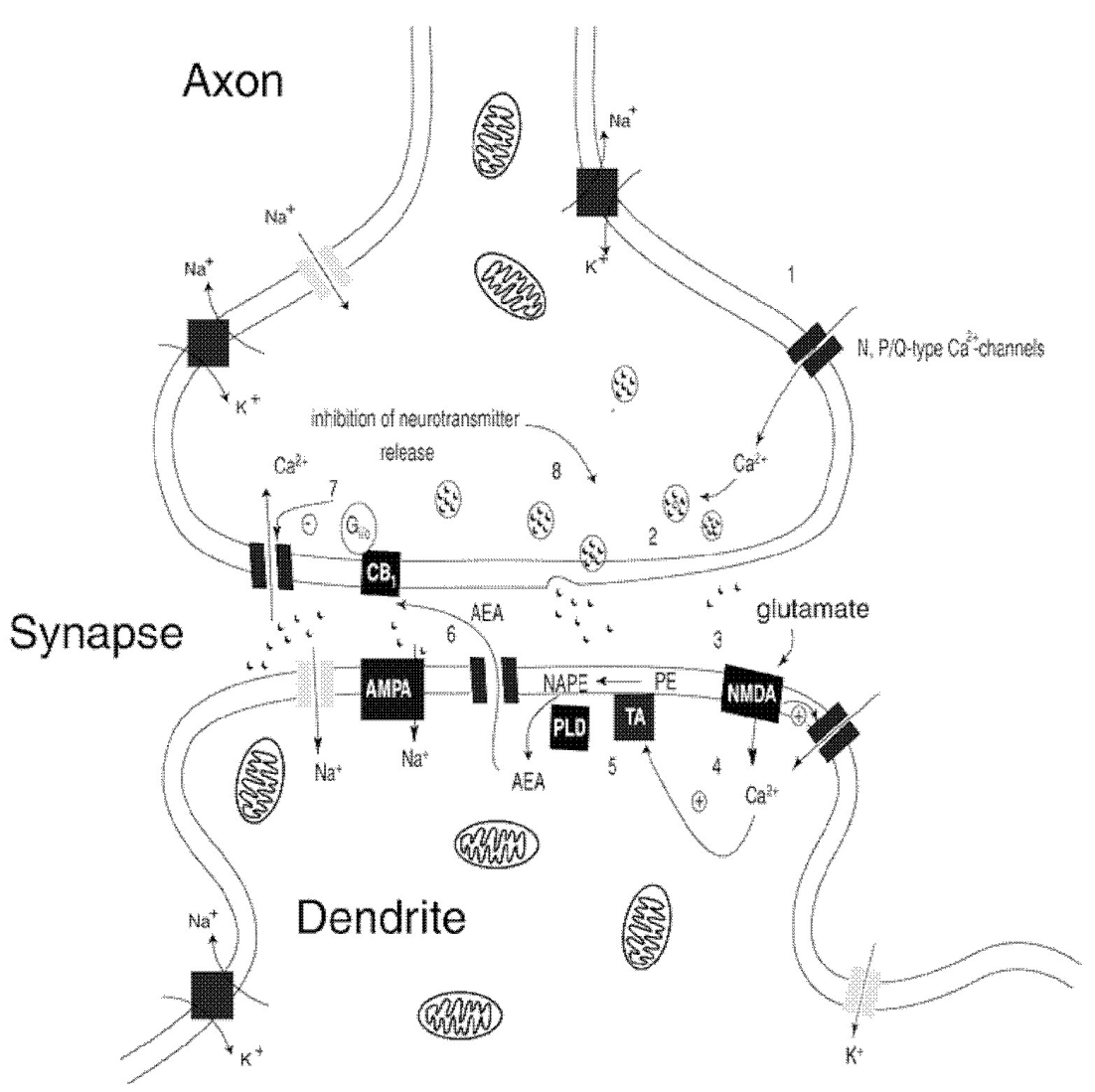

Figure 3. Model of hypothetical retrograde action of anandamide (AEA). (1) Presynaptic depolarization leads to calcium influx which in turn activates glutamate exocytosis. (2) Glutamate diffuses through synaptic cleft and activates postsynaptic glutamate receptors. (3) Activation of NMDA, AMPA and other glutamate subtype receptors leads to postsynaptic depolarization and calcium influx. (4) Elevated postsynaptic calcium levels activate a transacylase (TA) which converts phosphatidylethanolamine (PE) into N-arachidonoylphosphatidylethanolamine (NAPE). (5) NAPE is hydrolysed by a phospholipase D (PLD) which yields AEA. $A E A$ is released from the postsynaptic cell and diffuses back to the presynaptic $C B_{1}$ receptors. (6) Upon activation of the $C B_{1}$ receptors by $A E A$, Gi/o-proteins are released which inhibit $\mathrm{N}$-, and P/Q-type voltage-sensitive calcium channels. (7) Closing of voltage-sensitive calcium channels results in a reduced release of neurotransmitters (8) (Adapted from Curr Med Chem 2002; 9: 663-676).

$\mathrm{CB}_{1}$ and $\mathrm{CB}_{2}$, two $\mathrm{G}$ protein-coupled receptors primarily located in the CNS and periphery, respectively (103). While the $\mathrm{CB}_{2}$ receptors are highly expressed in immune-competent cells, detectable levels of the $\mathrm{CB}_{1}$ receptors are found not only in central and peripheral neuronal cells, but also in a number of other cell types such as the immune cells, astrocytes, reproductive tissue cells, and endothelial cells in renal and vascular tissues. In the brain, the $\mathrm{CB}_{1}$ receptors are most abundant in the areas controlling motor, cognitive, emotional, and sensory functions, i.e., the hippocampus, basal ganglia, cerebellum, cortex, thalamus, amygdala, and olfactory bulb $(104,105)$. During the last few years, the endocannabinoid system has emerged as a remarkable topic in the scientific community and many different regulatory actions both in the central and peripheral nervous systems have been attributed to the endocannabinoids. In this context, the synthesis of cannabinoid receptor agonists and antagonists, anandamide uptake blockers, and selective inhibitors of endocannabinoid degradation has triggered an exponential growth of studies $(106,107)$. This has opened new strategies in the treatment of pain, obesity, neurological diseases such as multiple sclerosis, and the emotional disturbances including depression and anxiety. Signal transduction and biological actions of endocannabinoids are summarized in Table 1 .

\section{THERAPEUTIC SIGNIFICANCE OF ENDOCANNABINOIDS}

\section{Endocannabinoids and analgesia}

Even though non-steroidal anti-inflammatory drugs (NSAIDs) are widely used for their analgesic effects, the underlying mechanism(s) are still puzzling. According to several reports, NSAIDs probably act on targets other than the inhibition of cyclooxygenases to counteract pain (108). The discovery of endocannabinoid binding sites in the substantia gelatinosa, an area involved with the transmission of pain signals, opened new insights into the nociception (109). In this context, antinociceptive effects of the endocannabinoids were reported in several pain models (110-112). Concomitant perfusion of the selective $\mathrm{CB}_{1}$ receptor antagonist, $\mathrm{AM}-251$, reverses the antinociceptive activity of indomethacin, indicating the involvement of $\mathrm{CB}_{1}$ receptors in the antinociceptive activity of this NSAID (113). 


\section{Table 1. Signal transduction and biological actions of endocannabinoids in the CNS}

\section{Biological actions:}

\section{Cortex, cerebellum and spinal cord}

Blockade of $\mathrm{N}$-methyl-D-aspartate (NMDA) receptors, control of tremor and spasticity.

\section{Basal ganglia, striatum and globus pallidus}

Control of psychomotor disorders, interference with dopamine transmission, inhibition of GABA-mediated transmission, induction of long-term depression, potentiation of GABA-mediated catalepsy.

\section{Thalamus, hypothalamus and hippocampus}

Control of pain initiation, control of wake-sleep cycles, control of thermogenesis, control of appetite and food intake, impairment of working memory, impairment of memory consolidation, inhibition of long-term potentiation, inhibition of glutamate-mediated transmission.

\section{Retina}

Control of scotopic vision

\section{Endocannabinoids and opioids}

The interaction between the endocannabinoids and opioids in treating pain has been extensively reviewed. It is worth mentioning that the endocannabinoids and opiates share a similar pharmacological profile. Both systems induce analgesia, hypothermia, sedation, hypotension, inhibition of intestinal motility and locomotor activity, changes in mood, and depression of the immune function (114-117). Moreover, the mechanism by which the endocannabinoids produce antinociception involves the release of spinal dynorphin (118). It is now well-established that opiates and endocannabinoids exhibit cross-tolerance and/or mutual potentiation for antinociception after chronic treatment $(119,120)$. It is suggested that the widespread reduction of the endocannabinoid 2-AG in the brain of morphine-tolerant rats accounts for the enhanced susceptibility to the neurodegenerative processes and premature aging following chronic exposure to morphine (121). A new insight into the molecular mechanisms of the crosstalk between the opiates and cannabinoids is further provided (122).

\section{Endocannabinoids and appetite}

Involvement of the endocannabinoid system in food-seeking behavior and obesity is well documented. Adipocytes appear to be a source of the endocannabonioids and related compounds. This, may lead to the speculation that alipose tissue is implicated in the peripheral disregulation of the endocannabinoid system during obesity (123). The endocannabinoid system has been suggested to act as a major mediator between brain, the alimentary system and the adipose tissue (124). Emerging data suggest that tetrahydrocannabinol acts via the $\mathrm{CB}_{1}$ receptors on hypothalamic nuclei and directly increases the appetite. In parallel, the hypothalamic neurons tonically produce the endocannabinoids which regulate hunger (125). It is worth mentioning that endocannabinoid contents are inversely correlated with the amount of leptin in blood. For example, mice without leptin not only become massively obese, but have higher-than-normal levels of hypothalamic endocannabinoids. Similarly, when these mice are treated with an endocannabinoid antagonist, food intake is reduced (126). Moreover, in $\mathrm{CB}_{1}$ receptor knock-out mice, the animals tend to be leaner and less hungry than wild-type mice (127). As aforementioned, the endocannabinoid system activate a pathway in the hypothalamus responsible for foodseeking behavior, as well as endocannabinoids might also affect the feeding behavior at the level of taste cells $(128,129)$.

\section{Endocannabinoids and reward system}

The presence of the endocannabinoid system in reward circuits and its role in motivational and emotional homeostasis suggests that compounds which modulate cannabinoid signalling might serve as diagnostic or therapeutic tools in drug addiction. In accordance with this rationale, the $\mathrm{CB}_{1}$ receptor antagonists have been shown to modulate opioid self-administration in rodents (130). Extending this hypothesis, converging research lines have established a role for the endocannabinoids and $\mathrm{CB}_{1}$ receptors in alcohol dependence $(131,132)$. According to the findings of an animal study, chronic exposure to nicotine, ethanol, or cocaine induces a brain region-specific changes in the endocannabinoid contents (133), therefore, it is likely that endocannabinoids mediate the anxiety-like symptoms induced by withdrawal from drugs of abuse.

\section{Endocannabinoids and ischaemia-reperfusion injury} Ischaemia-reperfusion is a pivotal mechanism of organ injury during stroke, myocardial infarction, organ transplantation, and vascular surgery. There is a marked increase of endocannabinoid production in various forms of ischaemiareperfusion which correlate with the degree of tissue injury 
and inflammation (134). Direct measurements usually confirm the increase of target tissue endocannabinoid levels following preconditioning. The involvement of the $\mathrm{CB}_{1} / \mathrm{CB}_{2}$ receptors may be determined by using knockout mice (135).

\section{Endocannabinoids and reproduction}

The role of the endocannabinoids in female reproduction is an emerging concept. In embryo implantation timing, the endocannabinoid system plays an important regulatory role (136). Cannabinoid receptors are expressed by the developing embryo and are responsive to the uterine anandamide which modulates the probability of implantation to the uterine wall (137). The likelihood of human miscarriage is increased if uterine anandamide levels are too high or low (138). These findings suggest that proper intake of exogenous cannabinoids can decrease the likelihood for pregnancy for women with high anandamide levels, and alternatively, it can increase the likelihood for pregnancy in women whose anandamide levels are too low.

\section{Endocannabinoids and cytotoxicity}

Since the first reference on antineoplastic action of endocannabinoids on lung adenocarcinoma and leukemia cells, there has been increasing evidence about the cytotoxic, proapoptotic and antineoplastic effects of endocannabinoids in vivo and in vitro $(139,140)$. Mitogen-activated protein kinase (MAPK)-dependent signaling, ceramide, oxidative stress, and lipid rafts appear to be involved in the triggering of apoptosis by the endocannabinoids (141). These authors represented the cannabinoids as potential anticancer agents either solo or in combination with other cancerostatics.

\section{Endocannabinoids and neuroprotection}

Regardless of the point of initiation, the neurotoxic events

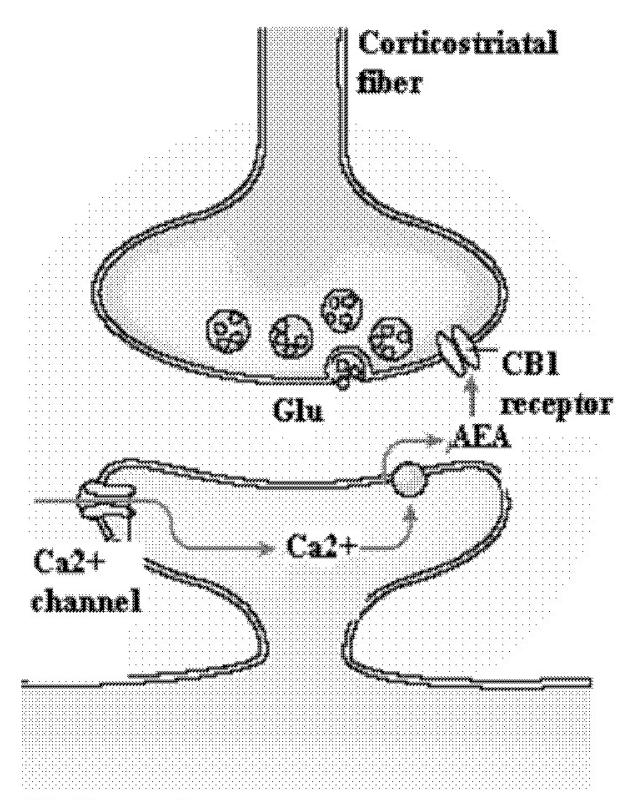

Mediun spiny newron

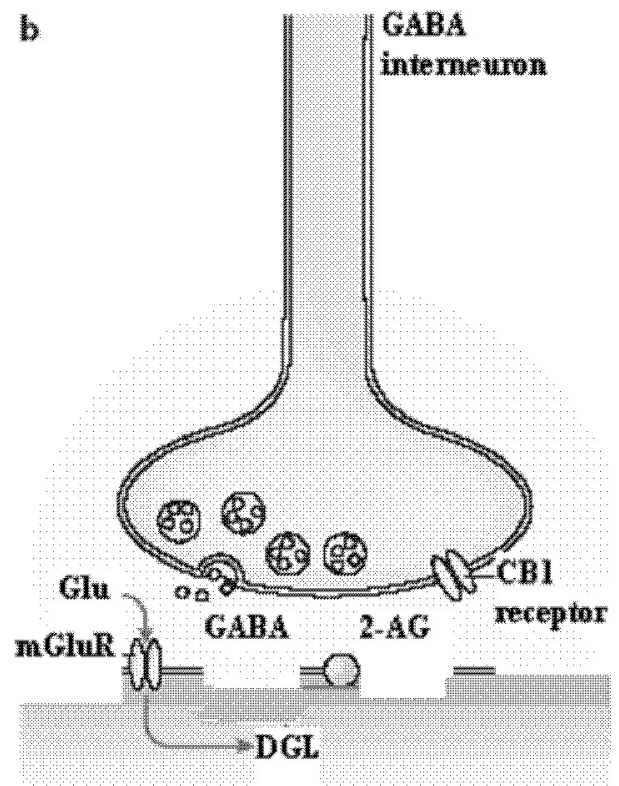

Pyramidal neuroun

Figure 4. Roles of the endocannabinoids in long-term synaptic plasticity. a) Repetitive activation of corticostriatal fibres causes a persistent reduction of glutamate release, called long-term depression (LTD) which might be mediated by anandamide (AEA). The elevated $\mathrm{Ca}^{2+}$ concentrations produced in postsynaptic spines of striatal medium spiny neurons after the stimulation could trigger anandamide formation which in turn might induce LTD by engaging $C B_{1}$ cannabinoid receptors on glutamatergic axon terminals. b) High-frequency stimulation of glutamatergic Schaffer collaterals in the hippocampus elicits a prolonged reduction of GABA ( $\gamma$-aminobutyric acid) release that might be mediated by 2-arachidonoylglycerol (2-AG). This heterosynaptic form of plasticity, called inhibitory-LTD (I-LTD) is induced when glutamate activates metabotropic receptors (mGluR) on pyramidal neurons, eliciting 2-AG formation through the diacylglycerol lipase (DGL) pathway. 2-AG might then travel sideways to engage the $C B_{1}$ receptors on contiguous terminals of GABA interneurons, producing I-LTD. (Adapted from Nat Rev Neurosci 2003; 4 : 873-884). 
self-amplify and ultimately lead to cell death (142). A unique opportunity to improve inflammation and neurodegeneration simultaneously might be offered by pharmacological agents that can modulate the activity of cannabinoid receptors (143). In animal model of brain injury, the neuroprotective action of the endocannabinoid 2-AG has been reported (144). In the experimental models of Alzheimer's disease, stimulation of either $\mathrm{CB}_{1}$ or $\mathrm{CB}_{2}$ receptor subtypes prevents microglial activation, microglia-mediated neurotoxicity, and neurodegeneration (145). The therapeutic potential of the cannabinoid receptor agonist WIN55212-2 against nigrostriatal degeneration is demonstrated (146). Degeneration of dopaminergic neurons during the experimental Parkinson's disease may be reduced by the agonists of $\mathrm{CB}_{1}$ or $\mathrm{CB}_{2}$ receptors (147). A link between the endocannabinid signalling in the globus pallidus and symptoms of the disease has been reported (148). Moreover, pharmacological agonists of cannabinoid receptors exert beneficial effects in amyotrophic lateral sclerosis (149).

In recent years, a growing interest has been attracted towards the therapeutic potentials of endocannabinoids in multiple sclerosis (MS). According to the historical records from ancient China and Greece, the preparations of Cannabis Indi$c a$ were commonly prescribed to ameloriate MS-like symptoms such as tremors and muscle pain (150). Afterwards, cannabis-based medicine were used for the treatment of MS. Due to the illegality of cannabis and rising number of MS patients undergoing self-medication, there has been much interest in exploiting the endocannabinoid system to provide a legal and effective relief (151). In the experimental models of MS, stimulation of either $\mathrm{CB}_{1}$ or $\mathrm{CB}_{2}$ receptors has been beneficial against the inflammatory process (152). In mouse models of MS, a profound reduction and reorganization of the $\mathrm{CB}_{1}$ receptors has been observed in the cerebellum (153). $\mathrm{CB}_{1}$ agonists promote both in vitro survival of oligodendrocytes and mRNA expression of myelin lipid protein (154). Moreover, the endocannabinoid 2-AG has been shown to stimulate proliferation of a microglial cell line through a $\mathrm{CB}_{2}$ receptor-dependent mechanism (155). Taken together, these studies point to the exciting possibility that cannabinoid treatment may not only be able to attenuate the symptoms of MS, but also improve oligodendrocyte function. Despite the potential benefits of drugs acting on the cannabinoid receptors, their clinical use is hampered mainly because of their psychotropic effects (156). Therefore, designing cannabinoid derivatives devoid of psychoactive side effects appears to be helpful in the management of the debilitating disease, MS.
In general, cannabinoids exert their neuroprotective responses through activation of the cannabinoid receptors $(157,158)$. However, cannabinoids may also protect neurons independent of the cannabinoid receptors. For example, WIN55, 212-2 may protect cerebral cortical neurons from in vitro hypoxia and glucose deprivation in a cannabinoid receptor-independent manner (159). Moreover, exogenous anandamide and 2-AG have been shown to protect cultured cerebral neurons against the toxic levels of the ligands of glutamate, AMPA, and kainate receptors in a cannabioid receptor-independent fashion (160).

The mechanisms through which the exogenous cannabinoids exert neuroprotection in a variety of in vitro and in vivo models of neuronal injury include: (i) prevention of the excitotoxicity through the $\mathrm{CB}_{1}$ receptor-mediated inhibition of glutamate transmission. This, is performed by closing the $\mathrm{N}$ - and P/Q-type Ca2 ${ }^{+}$channels (161), (ii) reduction of $\mathrm{Ca}^{2+}$ influx at both pre- and postsynaptic levels followed by inhibition of subsequent noxious cascades (162), (iii) antioxidant activity mainly owing to the phenol group of various resorcinol-type cannabinoids (163), (iv) suppression of the production of tumor necrosis factor- $\alpha$ (164), (v) activation of the phosphatidylinositol 3-kinase/protein kinase B pathway (165), (vi) induction of phosphorylation of extracellular regulated kinases (166), and (vii) induction of the expression of transcription factors and neurotrophins (167).

\section{Endocannabinoids and mood disorders}

As aforementioned, mood disorders represent a chronic debilitating disease group that are highly prevalent worldwide (1). Among all mental disorders, major depression has the highest rate of prevalence and incidence of morbidity. Drugs that directly influence the availability of brain monoamines, are considered as the primary medical treatment of depression (2). Unfortunately, the currently available antidepressant therapies have limited efficacies. Consequently, the research on new drugs for the treatment of mood disorders has become increasingly critical. Compelling evidence suggests that compounds which affect the endocannabinoid signalling not only modulate monoamine-mediated neurotransmission, but also affect the activity of the hypothalamic-pituitary-adrenal (HPA) axis (168). We have shown that activation of the endocannabinoid system is necessary for the suppression of HPA axis activity by tricyclic antidepressant doxepin (169). Recent preclinical evidences indicating the important roles of cannabinoid agonists or endocannabinoid enhancers (e.g. the 
fatty acid amide hydrolase (FAAH) inhibitors) in the regulation of mood, have opened a new line of research in antidepressant drug discovery (170). Endocannabinoids are present in moderate to high levels in limbic brain regions including the prefrontal cortex, hippocampus, and amygdala, where the neuronal activity is altered in depression (171). Deficiencies in the endocannabinoid signaling are associated with a behavioral phenotype similar to the symptom profile of severe depression (172). In this context, several pharmacological and somatic treatments against depression have been shown to increase the endocannabinoid neurotransmission which, in some cases, is required for the neurobiological adaptations elicited by these treatments (173). Cannabinoids and the related compounds may also exert a therapeutic potential in anxiety-related disorders (174). Patients treated with cannabinergic compounds for MS or chronic neuropathic pain, might also benefit from the anxiolytic effects of the cannabionids (175). Studies in animal models have shown that the $\mathrm{CB}_{1}$ receptor antagonist SR141716A induces anxiety-like responses (176). Meanwhile, psychoactive cannabinoids are able to induce both anxiolytic and anxiety-like reactions which are dose- and context-dependent (177).

The neurobiological mechanism(s) linking the endocannabinoid system with the pathophysiology of mood disorders and antidepressant action have remained somewhat elusive. Similar to the actions of conventional antidepressants, activation of the endocannabinoid signalling may result to the enhancement of serotonergic and noradrenergic transmission, cellular plasticity, and neurotrophin expression within the hippocampus $(178,179)$. We have shown that chronic exposure to a wide range of psychotropic medications including the NK receptor antagonists induce a significant elevation of both endocannabinoids anandamide and 2-AG in the brain regions which are implicated in the regulation of emotional behaviour and synaptic plasticity $(69,83)$. These findings suggest an existence of intrinsic endocannabinoid activity that contributes to the mechanisms of action of certain psychotropic drugs. In general, brain regional distribution of endocannabinoids following psychotropic treatment suggests that cannabinoid system may be integral to the development and maintenance of effective coping strategies to the emotional responses as well as achievement a better drug efficacy.

In our studies, endocannabinoid contents were increased within the brain regions in which psychotropic drugs were also able to elevate NGF production. Furthermore, $\mathrm{CB}_{1}$ re- ceptor neutral antagonist, AM4113, by blocking endogenous cannabinoid activity prevented psychotropic-induced enhancement of NGF $(69,83)$. These findings argue for $\mathrm{CB}_{1}$ mediated up-regulation of central NGF by psychotropic medications and are in agreement with previous reports suggesting an interaction between the endocannabinoid system and neurotrophins (93-95).

\section{CONCLUSION}

During the last few years, the increasing interest in the endocannabinoid system which is involved in the regulation of many cellular and physiological functions, has led to a number of interesting data derived from animal studies. Our recent findings demonstrate that the endocannabinoid system plays a pivotal role in the action of currently used psychotropic medications including the regulation of the HPA axis activity and brain regional levels of NGF. These findings may present an impetus for a better understanding of the complex scenario of the cannabinoid effects in humans as well as the pathophysiological mechanisms underlying neuropsychiatric disorders. Now, the time has arrived for clinical researchers to look at the cannabinoid system as a valuable target for drug discovery, especially in disorders for which no effective therapeutic or prophylactic regimens are presently available. As Eden Phillpotts (1862-1960) wrote, "The universe is full of magical things patiently waiting for our wits to grow sharper."

\section{REFERENCES}

1. Kessler RC, Berglund P, Demler O, Jin R, Koretz D, Merikangas KR, et al. The epidemiology of major depressive disorder. JAMA 2003; 289(23): 3095-3105.

2. Ressler KJ, Nemeroff CB. Role of serotonergic and noradrenergic systems in the pathophysiology of depression and anxiety disorders. Depress Anxiety 2000; 12: 2-19.

3. Holsboer F. The corticosteroid receptor hypothesis of depression. Neuropsychopharmacology 2000; 23: 477 501.

4. McEwen BS. Glucocorticoids, depression, and mood disorders: structural remodeling in the brain. Metabolism 2005; 54: 20-23.

5. Lu XY. The leptin hypothesis of depression: a potential link between mood disorders and obesity? Curr Opin Pharmacol 2007; 7: 648-652.

6. Gertler A. Role of leptin in early metabolic programming. Adipobiology 2009; 1: 27-34. 
7. Bun-Hee L, Aye-Mu M, Yong-Ku K. Psychotropic drugs on in vitro brain-derived neurotrophic factor production in whole blood cell cultures from healthy subjects. $J$ Clin Psychopharm 2010; 30: 623-627.

8. Manji HK, Moore GJ, Rajkowska G, Chen G. Neuroplasticity and cellular resilience in mood disorders. $\mathrm{Mol}$ Psychiatry 2000; 5: 578-593.

9. Reichardt LF. Neurotrophin-regulated signalling pathways. Philos Trans R Soc Lond B Biol Sci 2006; 361: 1545-1564.

10. Allen SJ, Dawbarn D. Clinical relevance of the neurotrophins and their receptors. Clin Sci 2006; 110: 175191.

11. Greene LA, Kaplan DR. Early events in neurotrophin signaling via Trk and p75 receptors. Curr Opin Neurobiol 1995; 5: 579-587.

12. Gallo G, Letourneau PC. Localized sources of neurotrophins initiate axon collateral sprouting. $J$ Neurosci 1998; 18: 5403-5414.

13. McAllister AK, Lo DC, Katz LC. Neurotrophins regulate dendritic growth in developing visual cortex. $\mathrm{Neu}$ ron 1995; 15: 791-803.

14. Song HJ, Ming GL, Poo MM. A cAMP-induced witching of turning direction of nerve growth cones. Nature 1997; 388: 275-279.

15. Lesser SS, Sherwood NT, Lo DC. Neurotrophins differentially regulate voltage-gated ion channels. Mol Cell Neurosci 1997; 10: 173-183.

16. Lohof AM, Ip NY, Poo MM. Potentiation of developing neuromuscular synapses by the neurotrophins NT-3 and BDNF. Nature 1993; 363: 350-353.

17. Kang H, Schuman EM. Long-lasting neurotrophininduced enhancement of synaptic transmission in the adult hippocampus. Science 1995; 267: 1658-1662.

18. Hans T. Neurotrophins and neuronal plasticity. Science 1995; 270: 593-598.

19. Poo MM. Neurotrophins as synaptic modulators. Nat Rev Neurosci 2001; 2: 24-32.

20. Schulte-Herbrüggen O, Jockers-Scherübl MC, Hellweg R. Neurotrophins: from pathophysiology to treatment in Alzheimer's disease. Curr Alzheimer Res 2008; 5: 3844.

21. Shaltiel G, Chen G, Manji HK. Neurotrophic signaling cascades in the pathophysiology and treatment of bipolar disorder. Curr Opin Pharmacol 2007; 7: 22-26.

22. Pacher P, Kohegyi E, Kecskemeti V, Furs S. Current trends in the development of new antidepressants. Curr Med Chem 2001; 8: 89-100.
23. Vaida VA, Duman RS. Depression: emerging insights from neurobiology. Br Med Bull 2001; 57: 61-79.

24. Warner-Schmidt JL, Duman RS. Hippocampal neurogenesis: opposing effects of stress and antidepressant treatment. Hippocampus 2006; 16: 239-249.

25. Dias BG, Banerjee SB, Duman RS, Vaidya VA. Differential regulation of brain derived neurotrophic factor transcripts by antidepressant treatments in the adult rat brain. Neuropharmacology 2003; 45: 553-563.

26. Nibuya M, Morinobu S, Duman RS. Regulation of BDNF and Trkb mRNA in rat brain by chronic electroconvulsive seizure and antidepressant drug treatment. $J$ Neurosci 1995; 15: 7539-7547.

27. Shirayama Y, Chen AC, Nakagawa S, Russell DS, Duman RS. Brain-derived neurotrophic factor produces antidepressant effects in behavioural models of depression. J Neurosci 2002; 22: 3251-3261.

28. Hashimoto K, Shimizu E, Iyo M. Critical role of brainderived neurotrophic factor in mood disorders. Brain Res Brain Res Rev 2004; 45: 104-114.

29. Karege F, Perret G, Bondolfi G, Schwald M, Bertschy G, Aubry JM. Decreased serum brain-derived neurotrophic factor levels in major depressed patients. Psychiatry Res 2002; 109: 143-148.

30. Chen B, Dowlatshahi D, MacQueen GM, Wang JF, Young LT. Increased hippocampal BDNF immunoreactivity in subjects treated with antidepressant medication. Biol Psychiatry 2001; 50: 260-265.

31. Shimizu E, Hashimoto K, Okamura N, Koike K, Komatsu N, Kumakiri C, et al. Alterations of serum levels of brain-derived neurotrophic factor (BDNF) in depressed patients with or without antidepressants. Biol Psychiatry 2003; 54: 70-75.

32. Siuciak JA, Lewis DR, Wiegand SJ, Lindsay RM. Antidepressant-like effect of brain-derived neurotrophic factor (BDNF). Pharmacol Biochem Behav 1997; 56: 131137.

33. Altar CA, Whitehead RE, Chen R, Wortwein G, Madsen TM. Effects of electroconvulsive seizures and antidepressant drugs on brain-derived neurotrophic factor protein in rat brain. Biol Psychiatry 2003; 54: 703-709.

34. Van Hoomissen JD, Chambliss HO, Holmes PV, Dishman RK. Effects of chronic exercise and imipramine on mRNA for BDNF after olfactory bulbectomy in rat. Brain Res 2003; 974: 228-235.

35. Alvin V, Terry J, Debra A, Warner GS, Hohnadel EJ, Middlemore ML, et al. Protracted effects of chronic oral haloperidol and risperidone on nerve growth fac- 
tor, cholinergic neurons, and spatial reference learning in rats. Neuroscience 2007; 150: 413-424.

36. Angelucci F, Aloe L, Gruber SHM, Fiore M, Mathé AA. Chronic antipsychotic treatment selectively alters nerve growth factor and neuropeptide $\mathrm{Y}$ immunoreactivity and the distribution of choline acetyl transferase in rat brain regions. Int J Neuropsychopharm 2000; 3: 13-25.

37. Vinay P, KhanMohammad M, Alvin T, Sahebarao PM. Differential effects of typical and atypical antipsychotics on nerve growth factor and choline acetyltransferase expression in the cortex and nucleus basalis of rats. $J$ Psychiat Res 2004; 38: 521-529.

38. Levi-Montalcini R. The nerve growth factors 35 years later. Science 1987; 237: 1154-1162.

39. Levi-Montalcini R, Skaper SD, Dal Toso R, Petrelli L, Leon A. Nerve growth factor: from neurotrophin to neurokine. Trends Neurosci 1996; 19: 514-520.

40. Levi-Montalcini R. The nerve growth factor and the neuroscience chess board. Prog Brain Res 2004; 146: 525-527.

41. Ebendal T. Function and evolution in the NGF family and its receptors. J Neurosci Res 1992; 32: 461-470.

42. Lad SP, Neet KE, Mufson EJ. Nerve growth factor: structure, function and therapeutic implications for Alzheimer's disease. Curr Drug Targets CNS Neurol Disord 2003; 2: 315-334.

43. Arredondo LR, Deng C, Ratts RB, Lovett-Racke AE, Holtzman DM, Racke MK. Role of nerve growth factor in experimental autoimmune encephalomyelitis. Eur $J$ Immunol 2001; 31: 625-633.

44. Aloe L, Tirassa P, bracci-Laudiero L. Nerve growth factor in neurological and non neurological diseases: Basic findngs and emerging pharmacological prospective. Curr Pharmacol Design 2001; 7: 113-123.

45. Tuveri M, Generine S, Matucci-Cenerini M, Aloe L. Nerve growth factor, a useful tool in the treatment of chronic vasculitis ulcers in rheumatoid arthritis. Lancet 2000; 356: 1739-1740.

46. Fiore M, Chaldakov GN, Aloe L. Nerve growth factor as a signalling molecule for nerve cells and also for the neuroendocrine-immune systems. Rev Neurosci 2009; 20: 133-145.

47. Sun W, Sun C, Lin H, Zhao H, Wang J, Ma H, et al. The effect of collagen-binding NGF-beta on the promotion of sciatic nerve regeneration in a rat sciatic nerve crush injury model. Biomaterials 2009; 30: 4649-4656.

48. Chaldakov GN, Fiore M, Stankulov IS, Manni L, Hristova MG, Antonelli A, et al. Neurotrophin presence in human coronary atherosclerosis and metabolic syndrome: a role for NGF and BDNF in cardiovascular disease? Prog Brain Res 2004; 146: 279-289.

49. Chaldakov GN, Fiore M, Tonchev AB, Dimitrov D, Pancheva R, Rancic G, et al. Homo obesus: a metabotrophin-deficient species. Pharmacology and nutrition insight. Curr Pharm Des 2007; 13: 2176-2179.

50. Lapchak PA, Araujo DM. NGF suppression of weight gain in adult female rats correlates with decreased hypothalamic cholecystokinin levels. Brain Res 1994; 655: 12-16.

51. Kawamoto K, Matsuda $\mathrm{H}$. Nerve growth factor and wound healing. Prog Brain Res 2004; 146: 369-84.

52. Tuveri MA, Triaca V, Aloe L. The nerve growth factor induces cutaneous ulcer healing in "non-responder" tranplanted skin. Ann Ist Super Sanita 2006; 42: 94-96.

53. Lambiase A, Manni L, Rama P, Bonini S. Clinical application of nerve growth factor on human corneal ulcer. Arch Ital Biol 2003; 141: 141-148.

54. Sornelli F, Fiore M, Chaldakov GN, Aloe L. Adipose tissue-derived nerve growth factor and brain-derived neurotrophic factor: results from experimental stress and diabetes. Gen Physiol Biophys 2009; 28: 179-183.

55. Chaldakov GN, Tonchev AB, Aloe L. NGF and BDNF: from nerves to adipose tissue, from neurokines to metabokines. Relevance to neuropsychiatric and cardiometabolic diseases. Riv Psichiatr 2009; 44: 79-87.

56. Heitz C, Descombes JJ, Miller RC, Stoclet JC. $\alpha$-adrenoceptor antagonistic and calcium antagonistic effects of nicergoline in the rat isolated aorta. Eur $J$ Pharmacol 1986; 123: 279-185.

57. Takahashi K, Akaike N. Nicergoline inhibits T-type $\mathrm{Ca}^{+}$channels in rat hipppocampal CA1 pyramidal neurons. Br J Pharmacol 1990; 100: 705-710.

58. Nishio T, Sunohara N, Furukawa S, Akiguchi I, Kudo Y. Repeated injections of nicergoline increase the nerve growth factor level in the aged rat brain. Jpn J Pharmacol 1998; 76: 321-323.

59. Hefti FF, Rosenthal A, Walicke PA, Wyatt S, Vergara G, Shelton DL, et al. Novel class of pain drugs based on antagonism of NGF. Trends Pharmacol Sci 2006; 27: 85-91.

60. Otten U, Baumann JB, Girard J. Stimulation of the pituitary-adrenocortical axis by nerve growth factor. Nature 1979; 282: 413-414.

61. Enzo E, Pierluigi P, Marika B, Piercarlo M, Marco B, Diego G. Raised plasma nerve growth factor levels associated with early-stage romantic love. Psychoneu- 
roendocrinology 2006; 31(3): 288-294.

62. Lim MM, Young LJ. Neuropeptidergic regulation of affiliative behavior and social bonding in animals. Horm Behav 2006; 50: 506-517.

63. Kendrick KM. The neurobiology of social bonds. JNeuroendocrinol 2004; 16: 1007-1008.

64. Angelucci F, Aloe L, Vasquez PJ, Mathe AA. Mapping the differences in the brain concentration of brain-derived neurotrophic factor (BDNF) and nerve growth factor (NGF) in an animal model of depression. Neuroreport 2000; 11(6): 1369-1373.

65. Chaldakov GN, Tonchev A, Aloe L. NGF and BDNF: from nerves to adipose tissue, from neurokines to metabokines. Relevance to neuropsychiatric and cardiometabolic. Riv Psichiatr 2009; 44: 79-87.

66. Parikh V, Evans DR, Khan MM, Mahadik SP. Nerve growth factor in never-medicated first-episode psychotic and medicated chronic schizophrenic patients: possible implications for treatment outcome. Schizophr Res 2003; 60: 117-123.

67. Alleva E, Petruzzi S, Cirulli F, Aloe L. NGF regulatory role in stress and coping of rodents and humans. Pharmacol Biochem Behav 1996; 54: 65-72.

68. Hassanzadeh P, Hassanzadeh A. Effects of different psychotropic agents on the central nerve growth factor protein. Iran J Basic Med Sci 2010; 13: 202-209.

69. Hassanzadeh P, Rahimpour S. The cannabinergic system is implicated in the upregulation of central NGF protein by psychotropic drugs. Psychopharmacology 2010; (doi 10.1007/s00213-010-2120-4, Epub ahead of print).

70. Hellweg R, Lang UE, Nagel M, Baumgartner A. Subchronic treatment with lithium increases nerve growth factor content in distinct brain regions of adult rats. Mol Psychiatry 2002; 7: 604-608.

71. Valvassori SS, Stertz L, Andrezza AC, Rosa MI, Kapczinski F, Streck EL, et al. Lack of effect of antipsychotics on BDNF and NGF levels in the hippocampus of rat. Metab Brain Dis 2008; 23: 213-219.

72. Pillai A, Terry Jr. AV, Mahadik SP. Differential effects of long-term treatment with typical and atypical antipsychotics on NGF and BDNF levels in rat striatum and hippocampus. Schizophr Res 2006; 82: 95-106.

73. Dableh LJ, Yashpal K, Rochford J, Henry JL. Antidepressant-like effects of neurokinin receptor antagonists in the forced swim test in the rat. Eur J Pharmacol 2005; 507: 99-105.

74. Griebel G, Perrault G, Soubrié P. Effects of SR48968, a selective non-peptide NK2 receptor antagonist on emotional processes in rodents. Psychopharmacology 2001; 158: 241-251.

75. Salomé N, Stemmelin J, Cohen C, Griebel G. Selective blockade of NK2 or NK3 receptors produces anxiolytic- and antidepressant-like effects in gerbils. Pharmacol Biochem Behav 2006; 83: 533-539.

76. Varty GB, Cohen-Williams ME, Morgan CA, Pylak U, Duffy RA, Lachowicz JE, et al. The gerbil elevated plus-maze II: anxiolytic effects of selective neurokinin NK1 receptor antagonists. Neuropsychopharmacology 2002; 27: 372-379.

77. Varty GB, Cohen-Williams ME, Hunter JC. The antidepressant-like effects of neurokinin NK1 receptor antagonists in a gerbil tail suspension test. Behav Pharmacol 2003; 14: 87-95.

78. Zocchi A, Varnier G, Arban R, Griffante C, Zanetti L, Bettelini L, et al. Effects of antidepressant drugs and GR 205171, an neurokinin-1 (NK1) receptor antagonist, on the response in the forced swim test and on monoamine extracellular levels in the frontal cortex of the mouse. Neurosci Lett 2003; 345: 73-76.

79. Bensaid M, Faucheux BA, Hirsch E, Agid Y, Soubrie P, Oury-Donat F. Expression of tachykinin NK2 receptor mRNA in human brain. Neurosci Lett 2001; 303: 25-28.

80. Pennefather JN, Lecci A, Candenas ML, Patak E, Pinto FM, Maggi CA. Tachykinins and tachykinin receptors: a growing family. Life Sci 2004; 74: 1445-1463.

81. Duric V, McCarson KE. Neurokinin-1 (NK-1) receptor and brain-derived neurotrophic factor (BDNF) gene expression is differentially modulated in the rat spinal dorsal horn and hippocampus during inflammatory pain. Mol Pain 2007; 3: 32.

82. Morcuende S, Gadd CA, Peters M, Moss A, Harris EA, Sheasby A, et al. Increased neurogenesis and brain-derived neurotrophic factor in neurokinin-1 receptor gene knockout mice. Eur J Neurosci 2003; 18: 1828-1836.

83. Hassanzadeh $\mathrm{P}$, Hassanzadeh A. Involvement of the cannabinoid and neurotrophin systems in the mechanisms of action of neurokinin receptor antagonists. Eur Neuropsychopharmacol 2011 (in press).

84. Banasr M, Valentine GW, Li XY, Gourley SL, Taylor JR, Duman RS. Chronic unpredictable stress decreases cell proliferation in the cerebral cortex of the adult rat. Biol Psychiat 2007; 62: 496-504.

85. Duman R. Depression: A case of neuronal life and death? Biol Psychiatry 2004; 56: 140-145.

86. Conner JM, Franks KM, Titterness AK, Russell K, Mer- 
rill DA, Christie BR, et al. NGF is essential for hippocampal plasticity and learning. J Neurosci 2009; 29: 10883-10889.

87. Winkler J, Ramirez GA, Thal LJ, Waite JJ. Nerve growth factor (NGF) augments cortical and hippocampal cholinergic functioning after p75NGF receptor-mediated deafferentation but impairs inhibitory avoidance and induces fear-related behaviors. J Neurosci 2000; 20(2): 834-844.

88. Donkin JJ, Nimmo AJ, Cernak I, Blumbergs PC, Vink, R. Substance P is associated with the development of brain edema and functional deficits after traumatic brain injury. J Cereb Blood Flow Metab 2009; 29: 1388-1398.

89. Vink R, Nimmo AJ, Cernak I. An overview of new and novel pharmacotherapies for use in traumatic brain injury. Clin Exp Pharmacol Physiol 2001; 28: 919-921.

90. Miwa T, Moriizumi T, Horikawa I, Uramoto N, Ishimaru T, Nishimura T, et al. Role of nerve growth factor in the olfactory system. Microsc Res Tech 2002; 58: 197 203.

91. Moises HC, Womble MD, Washburn MS, Williams LR. Nerve growth factor facilitates cholinergic neurotransmission between nucleus basalis and the amygdala in rat: an electrophysiological analysis. $J$ Neurosci 1995 ; 15: 8131-8142.

92. Bambico FR, Duranti A, Tontini A, Tarzia G, Gobbi G. Endocannabinoids in the treatment of mood disorders: evidence from animal models. Curr Pharm Design 2009; 15: 1623-1646.

93. Aso E, Ozaita A, Valdiza'n EM, Ledent C, Pazos A, Maldonado R. BDNF impairment in the hippocampus is related to enhanced despair behavior in CB1 knockout mice. J Neurochem 2008; 105: 565-572.

94. Williams EJ, Walsh FS, Doherty P. The FGF receptor uses the endocannabinoid signaling system to couple to an axonal growth response. $J$ Cell Biol 2003; 160: 481486.

95. Lemtiri-Chlieh F, Levine ES. BDNF evokes release of endogenous cannabinoids at layer $2 / 3$ inhibitory synapses in the neocortex. $J$ Neurophysiol 2010; 285: $19002-$ 19011.

96. Di Marzo V, Melck D, Bisogno T, De Petrocellis L. Endocannabinoids: endogenous cannabinoid receptor ligands with neuroremodulatory action. Trends Neurosci 1998; 21: 521-528.

97. Ferna'ndez-Ruiz JJ, Berrendero F, Herna'ndez ML, Ramos JA. The endogenous cannabinoid system and brain development. Trends Neurosci 2000; 23: 14-20.
98. Hungund BL, Basavarajappa BS. Are anandamide and cannabinoid receptors involved in ethanol tolerance? A review of the evidence. Alcohol Alcohol 2000; 35: 126133.

99. Yamamoto T, Takada K. Role of cannabinoid receptors in the brain as it relates to drug reward. Jpn J Pharmacol 2000; 84: 229-236.

100. Di Marzo V. Endocannabinoids and other fatty acid derivatives with cannabimimetic properties: biochemistry and possible physiopathological relevance. Biochim Biophys Acta 1998; 1392: 153-175.

101. Wilson RI, Kunos G, Nicoll RA. Presynaptic specificity of endocannabinoid signalling in the hippocampus. Neuron 2001; 31: 453-462.

102. Wilson RI, Nicoll RA. Endogenous cannabinoids mediate retrograde signalling at hippocampal synapses. $\mathrm{Na}$ ture 2001; 410: 588-592.

103. Hanus L, Gopher A, Almog S, Mechoulam R. Two new unsaturated fatty acid ethanolamides in brain that bind to the cannabinoid receptor. $J$ Med Chem 1993; 36: 3032-3034.

104. Redmer A, Kathmann M, Eberhard S. Cannabinoid $\mathrm{CB}_{1}$ receptor-mediated inhibition of hippocampal acetylcholine release is preserved in aged mice. Br J Pharmacol 2003; 138: 1425-1430.

105. Pertwee RG. Pharmacology of cannabinoid CB1 and CB2 receptors. Pharmacol Ther 1997; 74: 129-180.

106. Boger DL, Sato H, Lerner AE, Hedrick MP, Fecik RA, Miyauchi $\mathrm{H}$, et al. Exceptionally potent inhibitors of fatty acid amide hydrolase: the enzyme responsible for degradation of endogenous oleamide and anandamide. Proc Natl Acad Sci USA 2000; 97: 5044-5049.

107. Casanova ML, Blazquez C, Martinez-Palacio J, Villanueva C, Fernandez-Acenero MJ, Huffman JW, et $a l$. Inhibition of skin tumor growth and angiogenesis in vivo by activation of cannabinoid receptors. J Clin Invest 2003; 111: 43-50.

108. Brune K, Beck WS, Geisslinger G, Menzel-Soglowek S, Peskar BM, Peskar BA. Aspirin-like drugs may block pain independently of prostaglandin synthesis inhibition. Experientia 1991; 47: 257-261.

109. Herkenham M, Lynn AB, Johnson MR, Melvin LS, de Costa BR, Rice KC. Characterization and localization of cannabinoid receptors in rat brain: a quantitative in vitro autoradiographic study. J Neurosci 1991; 11: 563583.

110. Pertwee RG. Cannabinoid receptors and pain. Prog Neurobiol 2001; 63: 569-611. 
111. Calignano A, La Rana G, Giuffrida A, Piomelli D. Control of pain initiation by endogenous cannabinoids. $\mathrm{Na}$ ture 1998; 394: 277-281.

112. Calignano A, La Rana G, Loubet-Lescoulie P, Piomelli D. A role for the endogenous cannabinoid system in the peripheral control of pain initiation. Prog Brain Res 2000; 129, 471-482.

113. GÜhring H, Hamza M, Sergejeva M, Ates M, Kotalla $\mathrm{CE}$, Ledent C. A role for endocannabinoids in indomethacin induced spinal antinociception. Eu J Pharmacol 2002; 454: 153-163.

114. Welch SP, Eads M. Synergistic interactions of endogenous opioids and cannabinoid systems. Brain Res 1999; 848: 183-190.

115. Massi P, Vaccani A, Romorini S, Parolaro D. Comparative characterization in the rat of the interaction between cannabinoids and opiates for their immunosuppressive and analgesic effects. J Neuroimmunol 2001; 117: 116124.

116. Manzanares J, Corchero J, Romero J, Fernandez-Ruiz JJ, Ramos A, Fuentes JA. Pharmacological and biochemical interactions between opioids and cannabinoids. Trends Pharmacol Sci 1999; 20: 287-294.

117. Cichewicz DL, Martin Z, Smith FL, Welch, SP. Enhancement of opioid potency with inactive oral administration of D9-THC: Dose response analysis and receptor characterization. $J$ Pharmacol Exp Ther 1999; 289: 859-867.

118. Pugh GJ, Smith P, Dombrowski D, Welch SP. The role of endogenous opioids in enhancing the antinociception produced by the combination of D9-THC and morphine in the spinal cord. $J$ Pharmacol Exp Ther 1996; 279: 608-616.

119. Cichewicz DL, Haller VL, Welch SP. Changes in opioid and cannabinoid receptor protein following short-term combination treatment with D9-tetrahydrocannabinol and morphine. J Pharmacol Exp Ther 2001; 297: 121127.

120. Rowen DW, Embrey JP, Moore CH, Welch SP. Antisense oligodeoxynucleotides to Kappal receptor enhance D9-THC-induced antinociceptive tolerance. Pharmacol Biochem Behav 1998; 59: 399-404.

121. Sala M, Braida D, Leone MP, Calcaterra P, Frattola D, Gori E. Chronic morphine affects working memory during treatment and withdrawal in rats: possible residual longterm impairment. Behav Pharmacol 1994; 5: 570-580.

122. Vigano D, Cascio MG, Rubino T, Fezza F, Vaccani A, Di Marzo V, et al. Chronic morphine modulates the con- tents of the endocannabinoid, 2-arachidonoyl glycerol, in rat brain. Neuropsychopharmacology 2003: 28: 11601167.

123. Gonthier MP, Hoareau L, Festy F, Matias I, Valenti M, Bes-Houtmann $\mathrm{S}$, et al. Identification of the endocannabinoids and related compounds in human fatty cells. Obesity 2007; 15: 837-845.

124. Fride E. The endocannabinoid-CB receptor system: A new player in the brain-gut-adipose field. Biomed Rev 2006; 17: 23-42.

125. Kirkham TC, Tucci SA. Endocannabinoids in appetite control and the treatment of obesity. CNS Neurol Disord Drug Targets 2006; 5: 272-292.

126. Di Marzo V, Goparaju SK, Wang L, Liu J, Bátkai S, Járai Z, et al. Leptin-regulated endocannabinoids are involved in maintaining food intake. Nature 2001; 410 : 822-825.

127. Di Marzo V, Sepe N, De Petrocellis L, Berger A, Crozier $\mathrm{G}$, Fride E, et al. Trick or treat from food endocannabinoids? Nature 1998; 396: 636-637.

128. Kirkham TC, Williams CM, Fezza F, Di Marzo V. Endocannabinoid levels in rat limbic forebrain and hypothalamus in relation to fasting, feeding and satiation: stimulation of eating by 2-arachidonoyl glycerol. $\mathrm{Br} \mathrm{J}$ Pharmacol 2002; 136: 550-557. 129. Yoshida R, Ohkuri T, Jyotaki M, Yasuo T, Horio N, Yasumatsu K, et al. Endocannabinoids selectively enhance sweet taste. Proc Natl Acad Sci USA 2010; 107: 935-939.

130. Navarro M, Carrera MR, Fratta W, Valverde O, Cossu $\mathrm{G}$, Fattore L, et al. Functional interaction between opioid and cannabinoid receptors in drug self administration. J Neurosci 2001; 21: 5344-5350.

131. Hungund BL, Basavarajappa BS, Vadasz C, Kunos G, Rodriguez de Fonseca F, Colombo G, et al. Ethanol, endocannabinoids, and the cannabinoidergic signaling system. Alcohol Clin Exp Res 2002; 26: 565-574.

132. Basavarajappa BS, Hungund BL. Chronic ethanol increases the cannabinoid receptor agonist anandamide and its precursor $\mathrm{N}$-arachidonoylphosphatidyl-ethanolamine in SK-N-SH cells. J Neurochem 1999; 72: 522-528.

133. Gonza'lez S, Cascio MG, Fernandez-Ruiz J, Fezza F, Di Marzo V, Ramos JA. Changes in endocannabinoid contents in the brain of rats chronically exposed to nicotine, ethanol or cocaine. Brain Res 2002; 954: 73-81.

134. Beheshtian A, Salmasi AH, Payabvash S, Kiumehr S, Nezami BG, Rahimpour S, et al. Role of endogenous cannabinoids in ischemia/reperfusion injury following 
testicular torsion in rats. Int J Urol 2008; 15: 449-454.

135. Pacher P, Haskó G. Endocannabinoids and cannabinoid receptors in ischaemia-reperfusion injury and preconditioning. Br J Pharmacol 2008; 153: 252-262.

136. Wang H, Xie H, Dey SK. Endocannabinoid signaling directs periimplantation events. AAPS J 2006; 8: E425E432.

137. Das SK, Paria BC, Chakraborty I, Dey SK. Cannabinoid ligand-receptor signaling in the mouse uterus. Proc Natl Acad Sci USA 1995; 92 (10): 4332-4336.

138. Maccarrone $M$, Valensise $H$, Bari $M$, Lazzarin $N$, Romanini C, Finazzi-Agrò A. Relation between decreased anandamide hydrolase concentrations in human lymphocytes and miscarriage. Lancet 2000; 355: 13261329.

139. Munson AE, Harris LS, Friedman MA, Dewey WL, Carchman RA. Antineoplastic activity of cannabinoids. J Natl Cancer Inst 1975; 55: 597-602.

140. Jia W, Hegde1 VL, Singh NP, Sisco1 D, Grant S, Nagarkatti M. et al. $\Delta 9$-Tetrahydrocannabinol-induced apoptosis in jurkat leukemia T cells is regulated by translocation of bad to mitochondria. Mol Cancer Res 2006; 4: 549-562

141. Pushkarev VM, Kovzun OI. Antineoplastic and apoptotic effects of cannabinoids. N-acylethanolamines: protectors or killers? Exp Oncol 2008; 30: 6-21.

142. Pang Z, Geddes JW. Mechanisms of cell death induced by the mitochondrial toxin 3 nitropropionic acid: acute excitotoxic necrosis and delayed apoptosis. $J$ Neurosci 1997; 17: 3064-3073.

143. Jackson SJ, Diemel LT, Pryce G, Baker D. Cannabinoids and neuroprotection in CNS inflammatory disease. J Neurosci 2005; 25: 1904 -1913.

144. Panikashvili D, Simeonidou C, Ben-Shabat S, Hanus L, Breuer A, Mechoulam R, et al. An endogenous cannabinoid (2-AG) is neuroprotective after brain injury. Nature 2001; 413: 527-531.

145. Ramirez BG, Blázquez C, Gómez del Pulgar T, Guzmán M, de Ceballos ML. Prevention of Alzheimer's disease pathology by cannabinoids: neuroprotection mediated by blockade of microglial activation. J Neurosci 2005; 25: 1904-1913.

146. Price DA, Martinez AA, Seillier A, Koek W, Acosta Y, Fernandez E, et al. WIN55212-2, a cannabinoid receptor agonist, protects against nigrostriatal cell loss in the 1-methyl-4-phenyl-1,2,3,6-tetrahydropyridine mouse model Parkinson's disease. Eur J Neurosci 2009; 29: 2177-2186.
147. Lastres-Becker I, Molina-Holgado F, Ramos JA, Mechoulam R, Fernández-Ruiz J. Cannabinoids provide neuroprotection against 6-hydroxydopamine toxicity in vivo and in vitro: relevance to Parkinson's disease. Neurobiol Dis 2005; 19: 96-107.

148. Di Marzo V, Hill MP, Bisogno T, Crossman AR, Brotchie JM. Enhanced levels of endogenous cannabinoids in the globus pallidus are associated with a reduction in movement in an animal model of Parkinson's disease. Faseb J 2000; 14: 1432-1438.

149. Centonze D, Rossi S, Finazzi-Agrò A, Bernardi G, Maccarrone M. The Endocannabinoid system in multiple sclerosis and amyotrophic lateral sclerosis. Int Rev Neurobiol 2007; 82: 171-186.

150. Huntley A. A review of the evidence for efficacy of complementary and alternative medicines in MS. Int MS J 2006; 13: 5-12.

151. Baker D, Pryce G, Croxford JL, Brown P, Pertwee RG, Huffman JW, et al. Cannabinoids control spasticity and tremor in a multiple sclerosis model. Nature 2000; 404: 84-87.

152. Arevalo-Martin A, Vela JM, Molina-Holgado E, Borrell J, Guaza C. Therapeutic action of cannabinoids in a murine model of multiple sclerosis. J Neurosci 2003; 23: 2511-2516.

153. Cabranes A, Pryce G, Baker D, Fernández-Ruiz J. Changes in $\mathrm{CB}_{1}$ receptors in motor-related brain structures of chronic relapsing experimental allergic encephalomyelitis mice. Brain Res 2006; 1107 : 199-205.

154. Molina-Holgado E, Vela JM, Arévalo-Martín A, Almazán G, Molina-Holgado F, Borrell J, et al. Cannabinoids promote oligodendrocyte progenitor survival: involvement of cannabinoid receptors and phosphatidylinositol-3 kinase/Akt signaling. J Neurosci 2002; 22: 9742-9753.

155. Carrier EJ, Kearn CS, Barkmeier AJ, Breese NM, Yang $\mathrm{W}$, Nithipatikom K, et al. Cultured rat microglial cells synthesize the endocannabinoid 2-Arachidonylglycerol, which increases proliferation via a CB2 receptordependent mechanism. Mol Pharmacol 2004; 65: 9991007.

156. Fowler CJ. Pharmacological properties and therapeutic possibilities for drugs acting upon endocannabinoid receptors. Curr Drug Targets CNS Neurol Disord 2005; 4: 685-696.

157. Shen M, Thaye, SA. Cannabinoid receptor agonists protect cultured rat hippocampal neurons from excitotoxicity. Mol Pharmacol 1998; 54: 459-462. 
158. Hampson AJ, Grimaldi M. Cannabinoid receptor activation and elevated cyclic AMP reduce glutamate neurotoxicity. Eur J Neurosci 2001; 13: 1529-1536.

159. Nagayama T, Sinor AD, Simon RP, Chen J, Graham $\mathrm{SH}$, Jin K, Greenberg DA. Cannabinoids and neuroprotection in global and focal cerebral ischemia and in neuronal cultures. J Neurosci 1999; 19: 2987-2995.

160. Sinor AD, Irvin SM, Greenberg DA. Endocannabinoids protect cerebral cortical neurons from in vitro ischemia in rats. Neurosci Lett 2000; 278: 157-160.

161. Van der Stelt M, Veldhuis WB, Maccarrone M, Bär PR, Nicolay K, Veldink GA, et al. Acute neuronal injury, excitotoxicity and the endocannabinoid system. $\mathrm{Mol} \mathrm{Neu-}$ robiol 2002; 26: 317-346.

162. Diana MA, Bregestovski P. Calcium and endocannabinoids in the modulation of inhibitory synaptic transmission. Cell Calcium 2005; 37: 497-505.

163. Marsicano G, Moosmann B, Hermann H, Lutz B, Behl C. Neuroprotective properties of cannabinoids against oxidative stress: role of the cannabinoid receptor CB1. $J$ Neurochem 2002; 80: 448-456.

164. Croci T, Landi M, Galzin AM, Marini P. Role of cannabinoid $\mathrm{CB}_{1}$ receptors and tumor necrosis factor- $\alpha$ in the gut and systemic anti-inflammatory activity of SR141716 (Rimonabant) in rodents. Br J Pharmacol 2003; 140(1): 115-122.

165. Van der Stelt M, Di Marzo V. Cannabinoid receptors and their role in neuroprotection. Neuromolecular Med 2005; 7: 37-50.

166. Marsicano G, Goodenough S, Monory K, Hermann H, Eder M, Cannich, A. CB1 cannabinoid receptors and ondemand defense against excitotoxicity. Science 2003: 302: 84-88.

167. Khaspekov LG, Brenz Verca MS, Frumkina LE, Hermann H, Marsicano G, Lutz B. Involvement of brainderived neurotrophic factor in cannabinoid receptordependent protection against excitotoxicity. Eur J Neurosci 2004; 19: 1691-1698.

168. Barna I, Zelena D, Arszovszki AC, Ledent C. The role of endogenous cannabinoids in the hypothalamo-pituitaryadrenal axis regulation: in vivo and in vitro studies in CB1 receptor knockout mice. Life Sci 2004; 75: 2959-2970.

169. Hassanzadeh P, Hassanzadeh A. The role of the endocannabinoids in suppression of the HPA axis activity by doxepin. Iran J Basic Med Sci 2011 (in press).

170. Gobbi G, Bambico FR, Mangieri R, Bortolato M, Campolongo P, Solinas M, et al. Antidepressant-like activity and modulation of brain monoaminergic transmission by blockade of anandamide hydrolysis. Proc Natl Acad Sci USA 2005; 102: 18620-18625.

171. Manji HK, Drevets WC, Charney DS. The cellular neurobiology of depression. Nat Med 2001; 7: 541-547.

172. Hill MN, Gorzalka BB. Is there a role for the endocannabinoid system in the etiology and treatment of melancholic depression? Behav Pharmacol 2005; 16: 333-352.

173. Hill MN, Hillard CJ, Bambico FR, Patel S, Gorzalka $\mathrm{BB}$, Gobbi G. The therapeutic potential of the endocannabinoid system for the development of a novel class of antidepressants. Trends Pharmacol Sci 2009; 30 : 484493. 174. Haller J, Varga B, Ledent C, Barna I, Freund TF. Context dependent effects of CB1 cannabinoid gene disruption on anxiety-like and social behaviour in mice. Eur J Neurosci 2004; 19: 1906-1912.

175. Robson P. Therapeutic aspects of cannabis and cannabinoids. Br J Psychiatry 2001; 178: 107-115.

176. Navarro M, Hernandez E, Munoz RM, del Acro I, Villanua MA, Carrera MRA. Acute administration of the CB1 cannabinoid receptor antagonist SR141716A induces anxiety-like responses in the rat. Neuroreport 1997; 8: 491-496.

177. Patel S, Hillard CJ. Pharmacological evaluation of cannabinoid receptor ligands in a mouse model of anxiety: further evidence for an anxiolytic role for endogenous cannabinoid signaling. J Pharmacol Exp Ther 2006; 318: 304-310.

178. Jenny M, Schröcksnadel S, Überall F, Fuchs D. The potential role of cannabinoids in modulating serotonergic signaling by their influence on tryptophan metabolism. Pharmaceuticals 2010; 3: 2647-2660.

179. Galve-Roperh I, Aguado T, alazuelos J, Guzmán M. The endocannabinoid system and neurogenesis in health and disease. Neuroscientist 2007; 13: 109-114. 